\title{
The Current State of Informal Logic ${ }^{1}$
}

\section{J. ANTHONY BLAIR and RALPH H. JOHNSON University of Windsor}

What has come to be called "the informal logic movement"-by those who identify themselves with at least some members of a family of theses ${ }^{2}-$ can in retrospect be seen to have two origins. The first had to do with the question of what should be the subject matter of introductory logic instruction. Many instructors in what were labelled logic courses who wanted to teach good reasoning, with emphasis on the faithful interpretation and discriminating evaluation of arguments, came to believe that doing so by teaching formal deductive logic (either as the study of formal systems or as their application to natural language arguments) is ineffecient, and worse, leads to miseducation about reasoning and argumentation. (There has been some confusion about this point. The experience of these instructors is no ground for not teaching formal deductive logic, but it is an argument for not teaching it exclusively or as the central subject, in introductory courses devoted to reasoning and argumentation.)

In the U.S.A. and Canada, at least, there has been a striking increase in the number of informal logic courses and in the size of their enrollments, over the past $15-20$ years. In respect to its purpose as a reform movement in the teaching of introductory logic, informal logic is flourishing in these countries, and it has growing support in Britain, Australia and New Zealand as well.

Not everyone who would agree with the displacement of formal deductive logic as the central subject of such introductory courses has also recognized or fully-appreciated the second seminal influence in the informal logic movement, which was connected with logic theory as distinct from teaching. The theoretical breakaway was expressed in somewhat different ways by those who can be seen as its main progenitors: Chaim Perelman and Lucy OlbrechtsTyteca, Stephen Toulmin and Michael Scriven. ${ }^{3}$ We would describe their (independently expressed) insight as the recognition that formal deductive logic is not the logic of argumentation. Each may be seen as attempting to provide a correct account of this logic. We emphasize here the distinction between argument (or argumentation) as a communicative practice and argument as a set of statements between which implication relations allegedly hold. Unquestionably, formal deductive logic applies to the latter. Our point is that Perelman, Toulmin and Scriven saw that, in most cases, arguments as products of communication in such natural language practices as rational persuasion or rational inquiry are simply not chains of deductive inferences.

We find it frustrating that ten years after its more or less official launching at the First International Symposium, many who declare themselves sympathetic with the informal logic movement still do not appear fully to understand this insight and its implications. For too many, the ideal of "soundness" remains the paradigm of argument cogency, and informal logic is simply applied formal logic without symbols. Informal logic as a reform movement in logic theory, we regret to say, is still in its infancy.

We shall return to this point in a moment, but first we must weave another strand into the theoretical history of informal logic-the influence of the fallacy theory revival.

Besides Perelman, Toulmin and Scriven, the main figure associated with 
the emergence of informal logic is C.L. Hamblin, whose influential study, Fallacies (1970), drew attention to the informal fallacies and partly inspired the extensive work on them by John Woods and Douglas Walton. ${ }^{4}$ For many, informal logic is coextensive with the study of the informal fallacies.

There is irony here, and the reason is instructive. Hamblin's book, besides being a survey of historical treatments of (mostly informal) fallacies, was an extended lament for the lack of systematic, formal study of the informal fallacies, together with the sketch of a formal dialectical logic intended to provide them with a theoretical basis. For Woods and Walton, widely (and rightly) praised for their careful analyses of various informal fallacies, the goal has always explicitly been to provide a formal account of each such fallacy. Those who think that informal logic is inhospitable to the use of formal methods misunderstand this aspect of its theoretical direction. There is nothing incompatible between the aims of informal logic, properly understood, and the attempt to identify formal structures in the so-called informal fallacies. In calling for no more precision than the subject matter allows, we do not abandon the demand for as much precision as the subject matter allows. Whether the informal fallacies will be illuminated by formal treatments can be neither denied nor affirmed a priori. Informal logic is not opposed to formal analysis; it is opposed to the mistaken view that the subject matter of formal deductive logic is argument.

In the past we have resisted demands to define informal logic. We had no definition to offer, and in trying to break out of the powerful grip of the dominant conception of logic we felt the need to try to forge new ways of thinking without being fettered by a premature commitment to the strictures of a definition. Now we are more confident about the direction our theorizing is taking, and while we hesitate to call what follows a definition, it is a more specific characterization than we have been prepared to state heretofore.

We believe that informal logic is best understood as the normative study of argument. It is the area of logic which seeks to develop standards, criteria and procedures for the interpretation, evaluation and construction of arguments and argumentation used in natural language.

It follows that various studies of argumentation, from the sociological, linguistic, psychological, literary and political points of view may have pertinence for, but will be distinct from, informal logic. It also follows that to the extent that it is appropriate to require the inferences in certain kinds of argument to be deductively valid, informal logic will make reference to formal deductive logic.

So understood, informal logic faces a large number of research tasks, only some of which have been taken up and none of which (in our view) has accumulated a settled body of doctrine. There are now, more and more, opportunities to read papers at conferences, to publish in monographs and in journals (for instance, Informal Logic, or the new journal Argumentation, edited by Frans van Eemeren and Michel Meyer), and there is increased receptivity to informal logic scholalrship in nonspecialized philosophical journals as well. We now set out a list of some of these tasks, along with comments about the activity related to them. This list gives you, in capsule form and in no particular order of priority, our reading of the current state of informal logic.

1. A theory of fallacy. Here is the most thoroughly tilled land in the domain of informal logic. Anyone wishing to comment on any fallacy, or on fallacy theory in general, has a copious and growing literature to consult. Moreover, there are now at least two general theories of fallacy abroad. Woods and Walton's is that there is no single all-embracing account of informal fallacies, and that 
each argument type yields up its own more or less typical fruits of illogic. ${ }^{5}$ Van Eemeren and Grootendorst hold that informal fallacies can be accounted for as violations of the rules required for the resolution of disputes through rational discussion. ${ }^{6}$ We think it is time for a careful critical review of the informal fallacy literature and an attempt to identify various approaches or schools of thought within it and the main issues of contention between them.

2. A theory of argument. Much work, largely in speech act theory and communication studies, has already been done on the nature of argument and argumentation. Most of it, however, has not had a logician's orientation. Argument is a social activity with many dimensions. Fields as varied as political science, cognitive psychology, literary criticism and sociology can each find in argument a rich subject for examination. The proceedings of the 1986 Amsterdam argumentation conference confirm this claim. ${ }^{7}$ From the logical point of view, however, some theory of argument is needed to stand behind the theory of argument cogency. How should argument be conceived-as a proof? as persuasion? as a conversation? as a competition? as an interrogation? as an inquiry? as an address to an audience?-as all of these? Is there one central notion of argument, or is there a family of concepts? There are, we are learning, extensive and in many cases long-established bodies of literature on argument for the informal logician to assimilate: Dutch, German, Belgian, French, Swiss, American, Canadian-no doubt we overlook many others. ${ }^{8}$ A synoptic review of the international literature-a polyglot would be needed to write itwould be invaluable.

3. A theory of argument cogency. When is an argument cogent? And what are the best questions to ask in this regard? Should one take the point of view of an external judge or critic, or the point of view of the audience or person to whom the argument is directed?
Should the point of view be timeless, or constrained by historical or other contextual circumstances? Should one seek impersonal standards, or is success or effectiveness the correct reference? If "soundness" is not the correct paradigm, as we believe, then what should be its replacement? Clearly the answers to these questions will be related to the theory of argument one embraces. The literature on argument cogency is, to our knowledge, sparse, and as we noted earlier, no fully developed theory has been articulated to date.

4. Argument and rationality. Argument is conceived by some as rational persuasion, by others as a rational way to resolve disagreements, by others as a means of rational inquiry. What is the nature of the connection between argument and rationality, and between the theory of argument and the theory of rationality? Often, standards of argument cogency make an appeal to rationality. Where do argument and argumentation fit in the larger framework of human rational enterprise?

5. The psychology of argumentation. In the last few years the obsessive fear of psychologism has been overcome to the extent that some logicians and epistemologists have begun to recognize and welcome the applications to their endeavours of research in cognitive psychology. For example, if humans actually do reason in certain ways that appear to be successful, but a theory implies that their reasoning is faulty, what follows? Are the people wrong or is the theory wrong? Also, cognitive psychologists appear increasingly open to studying reasoning other than that exemplified in syllogistic and propositional patterns, so their findings may have increased relevance for the teaching of reasoning in general and of informal logic in particular.

6. Fields of argument. Toulmin et al have postulated that argument standards vary from field to field. ${ }^{9}$ What is a field of argument? Does argument differ when 
in law, philosophy, psychology, history, politics, and so on? Does it differ as between theoretical use and practical use? In pursuing answers to these questions, informal logicians need to absorb the extensive research, both theoretical and empirical, reported in the speech communication literature since the early 1960s. The questions have obvious significance for theory of argument cogency, and for theory of argument in general.

7. The teaching of informal logic. As we have noted, the informal logic movement was initiated in large part by a concern that the topics taught in logic courses be appropriate to their advertised goals. What should the content of an informal logic course be, and what are the best methods for teaching this material? These questions have been discussed in Informal Logic and Teaching Philosophy, but they deserve more attention, and that includes attention to the problem of measuring success in such teaching.

8. The connection between informal logic and critical thinking. The American education reform movement marching under the banner of "critical thinking" has received a major contribution from many of the introductory logic instructors who were also instrumental in the development of informal logic. What exactly is the connection between informal logic and critical thinking? We understand informal logic to be a subject, with a theory to be developed and applied. Critical thinking, in contrast, is an activity-a practical virtue, Aristotle would have called it. At least part, but by no means all, of the theoria of critical thinking comes from informal logic-to the extent that dealing with arguments is important to critical thinking. Much writing on the subject is devoted to defining critical thinking ${ }^{10}-a$ highly contentious issue, partly because budgets and power ride on the outcome-and so far as we know only Harvey Siegel has tried at length to state the connection between the two. ${ }^{11}$
9. Informal logic and cognate fields. What are the overlaps and connections between informal logic and: rhetoric, speech act theory, epistemology, philosophy of language, debate, communication theory? As substantive work in the field of informal logic grows, it will be important to place this work in its relationship to that in these other areas. Is it part of a new discipline, which Charles Willard thinks is emerging? ${ }^{12}$

In "The Philosophical and Pragmatic Significance of Informal Logic" delivered as a peroration at the First International Symposium on Informal Logic (1978)-Michael Scriven said: “Informal logic can serve as the fountainhead for a new flood of intellectual revolutions, not only in logic, but across the whole landscape of the mind." It certainly seems to us that something very like a revolution is underway yet again in philosophy, especially if one looks at recent work in epistemology and ethics. We would not claim that these changes are the result of the emergence of informal logic, though when one considers the centrality of logic in the positivist research program, it would hardly be surprising to discover that changes in the conception of logic would have repercussions elsewhere.

Even if Scriven's hope for informal logic as embodied in the above quote now appears excessive, the restiveness that inspired it is not. The spirit of reevaluation that seems to have emerged in philosophy is at work in the informal logic movement.

\section{Notes}

1. An earlier version of this paper was presented at the XXVIII World Congress of Philosophy at Brighton, England, August 21, 1988, at the joint session organized by the Association for Informal Logic and Critical Thinking and the International Society for the Study of Argumentation. 
2. See, for example, the Appendix to our paper, "The Recent Development of Informal Logic," in J. Anthony Blair \& Ralph H. Johnson, eds., Informal Logic: The First International Symposium (Inverness, CA: Edgepress, 1980), pp. 25-26.

3. Chaim Perelman and L. OlbrechtsTyteca, The New Rhetoric (Notre Dame: University of Notre Dame, 1969), trans. John Wilkinson and Purcell Weaver [original French edition, La Nouvell Rhetorique (Paris: Presses Universitaires de France, 1958)]; Stephen Edelston Toulmin The Uses of Argument (Cambridge: Cambridge University Press, 1958); Michael Scriven, Reasoning (New York: McGraw-Hill, 1976).

4. C.L. Hamblin, Fallacies (London: Methuen, 1970), reissued by Vale Press, Newport News, Virginia, 1986. For a bibliography of Woods and Walton's work on fallacies see "Selected Supplementary Bibliography: Fallacies" in the special issue of Argumentation on Fallacies edited by John Woods, Vol. 1, No. 3, 1987, pp. 351-353, and see also John Woods and Douglas Walton, Fallacies: Selected Papers, 1972-1982 (Dordrecht and Providence: Foris, forthcoming).

5. See John Woods and Douglas Walton, Argumentation: The Logic Of The Fallacies (Toronto: McGrawHill Ryerson, 1982) and Douglas Walton, Informal Fallacies (Amsterdam and Philadelphia: John Benjamins, 1987).

6. For a succinct version of their theory see Frans $\mathrm{H}$. van Eemeren and Rob Grootendorst, "Fallacies in PragmaDialectical Perspective," Argumentation, Vol. 1, No. 3, 1987, pp. 283-301.

7. Argumentation: Across the Lines of Discipline, Argumentation: Perspectives and Approaches, and Argumentation: Analyses and Practices, eds. Frans $H$. van Eemeren, Rob Grootendorst, J. Anthony Blair and Charles A. Willard (Dordrecht: Foris, 1987).

8. Among the Dutch: Barth, van Eemeren, Grootendorst, Krabbe, Kruiger; among the Germans: Lorenz, Lorenzen; among the Belgians: Apostel, Meyer, Perelman, Olbrechts-Tyteca; among the French: Anscombre, Ducrot; among the Swiss: Borel, Grize; among the Americans: Brockriede, Ehninger, Farrell, Fisher, Jackson, Jacobs, O'Keefe, Johnstone, Wenzel, Willard; among the Canadians: Blair, Govier, Hitchcock, Johnson, Walton, Woods.

9. See Stephen Toulmin, Richard Rieke and Alan Janik, An Introduction to Reasoning, 2nd edition (New York: Macmillan; London: Collier Macmillan, 1984).

10. See, for example, definitions by Robert H. Ennis, "Rational Thinking and Educational Practice," in Philosophy and Education, ed. Jonas F. Soltis, Chicago: NSSE, 1981; by John E. McPeck, Critical Thinking and Education (Oxford: Martin Robertson, 1981), by Barry Beyer, "Critical Thinking, Social Education (April 1985). There are many others.

11. See his Educating Reason: Rationality, Critical Thinking and Education, (New York and London: Rutledge, 1988)

12. See the paper by Charles A. Willard in Norms and Argumentation, Robert Maier, ed. (Dordrecht, Providence: Foris, forthcoming) the proceedings of the 1988 Utrecht conference on that topic.

J. Anthony Blair and Ralph $\mathbf{H}$. Johnson, Department of Philosophy, University of Windsor, Windsor, Ontario, Canada N9B 3P4 